\title{
Clinical Trial of Nanoencapsulated Centella asiatica and Zingiber officinale to Improve Cellulite and Subcutaneous Adipolysis
}

\author{
Ani Kristiyani ${ }^{1}$, Zullies Ikawati ${ }^{1,}{ }^{*}$, Yenny Meliana ${ }^{2}$, Reza Yuridian Purwoko ${ }^{3}$ \\ ${ }^{1}$ Faculty of Pharmacy, Universitas Gadjah Mada, Yogyakarta, INDONESIA. \\ ${ }^{2}$ Research Centre for Chemistry, LIPI, Jakarta, INDONESIA. \\ ${ }^{3}$ Ergia Klinik Skin Care \& Research Yogyakarta, INDONESIA.
}

\begin{abstract}
Objective: The purpose of this study was to determine the effect of nanoencapsulated Centella asiatica and Zingiber officinale extract, with the dose of $3000 \mathrm{mg} / \mathrm{day}$, in reducing cellulite and improving the composition of subcutaneous adipose. Methods: This study used the quasi-experimental with pre and post-controlled design using 38 female subjects who suffer cellulite and have $\mathrm{BMI}>25$, and met the inclusion and exclusion criteria. Subjects were grouped randomly into the 28-day treatment group, the 42-day treatment group, and control group. Subjects in the treatment groups received the tested herbal with 3000 mg/day $(2 \times 3$ capsules @500 mg) that should be taken in determined duration. Appearance of cellulite and lipid profile were observed and body composition analysis was performed before and after treatment. Data were analyzed using T-test, Wilcoxon or Mann-Whitney, while the comparison of the three treatment groups was tested with ANOVA with 95\% confidence level $(p<0.05)$. Results: The administration of the drug for 28 days can significantly repair the cellulite grade. There was a significant improvement in cholesterol/HDL ratio, which showed that the 28-day treatment group was better than the 42-day treatment group. Compared to control group, the 28-day and the 42-day treatment
\end{abstract}

groups showed better clinical improvements in total cholesterol, LDL, the ratio of $\mathrm{LDL} / \mathrm{HDL}$, fasting blood sugar, weight, BMI, body fat, body fat percentage, left and right arm fat, trunk fat, left thigh fat, and cellulite grade. Conclusion: Nanoencapsulated extract of $C$. asiatica and $Z$. officinale can improve cellulite, lipid profile, and subcutaneous fat.

Key words: Centella asiatica, Zingiber officinale, Cellulite, Subcutaneous fat.

Key Messages: Nanoencapsulated herbal extracts consisting of Centella asiatica and Zingiber officinale can improve cellulite and reduce subcutaneous fat.

\section{Correspondence}

Prof. Dr. Zullies Ikawati, Faculty of Pharmacy, Universitas Gadjah Mada Yogyakarta, INDONESIA.

Phone: +62 8156854012

Email: zullies_ikawati@ugm.ac.id

DOI: 10.5530/jyp.2018.10.76

\section{INTRODUCTION}

Cellulite is a condition which the appearance of the skin resembles the skin of an orange or mattress due to a change in adipose tissue and microcirculation of blood and lymphatic disorders that caused connective tissue thickened and hardened. Cellulite is more common in women than men and usually occurs in parts of the body that contain adipose subcutaneous tissue, such as thigh, abdomen, and buttock, where there are adrenergic receptors in those sections. ${ }^{1-2}$

We developed a herbal formula consisting of Centela asiatia leaf extract and Zingiber officinale rhizome extract in nano particle form to enhance to solubility and bioavailability. Preclinical study of the formula has been conducted by our group to observe the effect of the combination to increase collagen synthesis and induce lipolysis in rat model. The results showed that administration of the herbal formula in $200 \mathrm{mg} / \mathrm{kg}$ for 30 days could increase collagen synthesis in skin tissue and decrease diameter of skin adipocyte cells. $^{3}$

The use of novel drug delivery systems can enhance bioavailability of herbal drugs by increasing the permeability and solubility. Nanoparticles formulation has advantages in the stability and long-term storage as well as efficient delivery systems for both hydrophilic and hydrophobic compounds. In addition, encapsulation guaranteed bioavailability enhancement and sustained release of the drug. ${ }^{4}$

According to Bylka et al. ${ }^{5}$ C. asiatica leaf contains triterpene that can increase the metabolism of lysine, proline, and amino acids. Triterpene also functioned as a collagen builder. Because of its ability to increase the synthesis of collagen, C. asiatica leaf is widely used as skin care products, especially to restore the elasticity and skin decay. Its mechanism of action is by increasing the proliferation of fibroblasts, collagen synthesis, and intracellular fibronectin. It is also increased the strength of newly formed skin strains and inhibits the inflammatory phases of hypertrophic and keloid scars, which can be used for anti-cellulite, photoaging, and striae. ${ }^{6}$ Key components isolated from Z . officinale, such as gingerol, shogaol, and paradols, have been observed for their antioxidant and anti-inflammatory activities. ${ }^{7-9}$ The anticellulite effect of red ginger is related to the inhibition of reactive oxygen species (ROS) activity. Ahmed et al. ${ }^{10}$ reported that red ginger significantly decreases lipid peroxidation in the animal through the activation of antioxidant enzymes, such as superoxide dismutase, catalase, and glutathione peroxidase. This effect is comparable to the effect of vitamin $\mathrm{C}$ as an antioxidant.

In this study, clinical trials was conducted to confirm the effect of nanoencapsulated extract of $C$. asiatica leaf and red ginger in decreasing cellulite. This clinical trial research is expected to obtain information about the effects and period of administration of the nanoencapsulated extract of C. asiatica leaf and red ginger to cellulite and lipid composition under the skin.

\section{MATERIAL AND METHODS}

The tested herbal product was prepared by Research Centre for Chemistry, Indonesian Institute of Science, Jakarta. The formula of

This is an open access article distributed under the terms of the Creative Commons Attribution-NonCommercial-ShareAlike 4.0 License, which allows others to remix, tweak, and build upon the work non-commercially, as long as the author is credited and the new creations are licensed under the identical terms. 
nanoencapsulated extracts has been patented with the registration number of P00201507472. The composition is shown in Table 1, which is prepared in $500 \mathrm{mg}$ capsule.

The research design used in this research was the quasi-experimental with pre and post-controlled design. The ethical clearance had been obtained from the Research Ethics Committee of Faculty of Medicine Gadjah Mada with number of KE/FK/123/EC/2016. Participants who have met inclusion and exclusion criteria were then grouped into three groups: control group (without receiving the test drug), the 28-day treatment group (receiving the test drug for 28 days), and the 42-day treatment group (receiving the test drug for 42 days). The exclusion criteria were subjects who are suffering or have significant clinical health disorders, such as haematology, kidney, endocrine, lung, gastrointestinal, cardiovascular, liver, psychiatric, nervous, or allergic diseases (including allergies to certain drugs), pregnant or planning to become pregnant during the testing period, breastfeeding, using hormonal contraceptives, smoking, consuming alcoholic beverages, and using drugs that affect the lipid profile one week before or during clinical trials. The dose of tested drug was 3000 mg/day ( 2 x 3 capsules @500 mg/day) according to calculation from preclinical study by Ikawati et al. ${ }^{3}$

This research was conducted in Ergia Skin Care Clinic and Research and HI-lab Laboratory of Yogyakarta. This research used GAIA 359 PLUS for Body Composition Analysis (BCA) examination. Grade cellulite was diagnosed by dermatologist and documented in photograph. Test subjects were required to bring home a control card. This was done to help subjects to remember taking the medication, keeping track of daily caloric and fat intake, and taking notes on exercise. Examination results during clinical test covering lipid profile, BCA examination, and cellulite grade were tabulated. After that, tabulated data were compared between pre and post of each treatment group using T-test, Wilcoxon or Mann-Whitney, while the comparison of the three treatment groups was tested with ANOVA with 95\% confidence level ( $\mathrm{p}<0.05)$.

\section{RESULTS}

Initially, there were 45 subjects registered in this study. However, 7 subjects were excluded. Out of 38 subjects, 16 subjects were grouped in the

Table 1: Composition of Nanoencapsulated C. asiatica and Z. officinale extract.

\begin{tabular}{|c|c|c|c|c|c|}
\hline & Raw & naterial & & $\begin{array}{l}\text { Percentage } \\
\text { (weight) }\end{array}$ & $\begin{array}{c}\text { Percentage } \\
\text { Total }\end{array}$ \\
\hline \multirow{6}{*}{ Nanoemulsion } & \multirow{5}{*}{$\begin{array}{c}\text { Oil } \\
\text { Phase }\end{array}$} & $\begin{array}{l}\text { C. asiatica } \\
\text { Extract }\end{array}$ & $\begin{array}{c}5 \% \\
(1 \mathrm{mg})\end{array}$ & \multirow{4}{*}{$\begin{array}{c}20 \% \\
(20 \mathrm{mg})\end{array}$} & \multirow{6}{*}{$\begin{array}{c}20 \% \\
(100 \mathrm{mg})\end{array}$} \\
\hline & & $\begin{array}{l}\text { Z. officinale } \\
\text { Extract }\end{array}$ & $1 \%$ & & \\
\hline & & Avocado Oil & $\begin{array}{c}88.5 \% \\
(17.7 \mathrm{mg})\end{array}$ & & \\
\hline & & $\begin{array}{l}\text { Surfactant } \\
\text { (Span 80) }\end{array}$ & $\begin{array}{c}5.5 \% \\
(1.1 \mathrm{mg})\end{array}$ & & \\
\hline & & Water & $\begin{array}{c}98 \% \\
(78.4 \mathrm{mg})\end{array}$ & $80 \%$ & \\
\hline & $\begin{array}{l}\text { Water } \\
\text { Phase }\end{array}$ & $\begin{array}{c}\text { Surfactant } \\
\text { (Propylene } \\
\text { Glycol) }\end{array}$ & $\begin{array}{c}2 \% \\
(1.6 \mathrm{mg})\end{array}$ & $(80 \mathrm{mg})$ & \\
\hline \multirow[t]{2}{*}{ Carrier } & \multicolumn{3}{|c|}{ Malto Dextrin } & $\begin{array}{c}90 \% \\
(350 \mathrm{mg})\end{array}$ & $80 \%$ \\
\hline & \multicolumn{3}{|c|}{ Gum Arabic } & $\begin{array}{c}10 \% \\
(40 \mathrm{mg})\end{array}$ & $(400 \mathrm{mg})$ \\
\hline
\end{tabular}

28-day treatment group and 22 were grouped in the 42 -day treatment group, which 11 of them were previously in the control group before the treatment was started. Two people from the 42-day treatment group dropped out. One subject dropped out due to typhoid fever at the end of the study and could not perform the final examination, whereas the other test subject dropped out because the subject had contraception injection in the last fifteen days before the end of the research. Therefore, there were 36 subjects who have completed the test and the data can be analyzed.

\section{Characteristics of participants}

The baseline data showed that the control group has the same characteristics as the 42-day treatment group, whereas there were some differences in their characteristics compared with the 28-day treatment groups. However, differences in baseline data are not considered to have effects on the outcome because each subject was analyzed individually. Comparison of characteristics of participants among the three groups is listed in Table 2.

\section{Participants's lifestyle evaluation and compliance}

Lifestyle in this study is referred to diet and exercise that were conducted during the study. The food consumption was recorded daily by the participants. The results of the food records consumed were calculated for its calories and fats then compared with caloric needs. Similarly,

Table 2: Baseline Characteristics of Research Subjects in Control Group, the 28-day Treatment Group, and the 42-day Treatment Group.

\begin{tabular}{|c|c|c|c|}
\hline $\begin{array}{l}\text { Baseline characteristics of } \\
\text { Patients }\end{array}$ & $\begin{array}{c}\text { Control } \\
n=11 \\
\text { Mean } \pm \text { SD }\end{array}$ & $\begin{array}{l}\text { the 28-day } \\
\text { Treatment } \\
\quad n=16 \\
\text { Mean } \pm \text { SD }\end{array}$ & $\begin{array}{l}\text { the 42-day } \\
\text { Treatment } \\
n=20 \\
\text { Mean } \pm \text { SD }\end{array}$ \\
\hline Triglyceride (mg/dL) & $99.09 \pm 74.08$ & $134.88 \pm 71,92$ & $89.10 \pm 45.94$ \\
\hline Total Cholesterol (mg/dL) & $169.64 \pm 20.98$ & $189.06 \pm 36.07$ & $178.65 \pm 23.83$ \\
\hline $\mathrm{HDL}(\mathrm{mg} / \mathrm{dL})$ & $46.35 \pm 8,34$ & $45.18 \pm 9,33$ & $49.35 \pm 11.67$ \\
\hline $\mathrm{LDL}(\mathrm{mg} / \mathrm{dL})$ & $107.55 \pm 19,16$ & $120.63 \pm 29,85$ & $117.80 \pm 16.78$ \\
\hline Cholesterol/HDL Ratio & $3.78 \pm 0.87$ & $4.311 \pm 1.10$ & $3.73 \pm 0.68$ \\
\hline LDL/HDL Ratio & $2.38 \pm 0.56$ & $2.77 \pm 0.85$ & $2.48 \pm 0.54$ \\
\hline Fasting Blood Sugar (mg/dL) & $88.27 \pm 5.02$ & $91.19 \pm 7.64$ & $88.65 \pm 7.21$ \\
\hline Weight (kg) & $70.73^{+} \pm 11.19$ & $84.68^{\star} \pm 15.23$ & $73.83 \pm 13.66$ \\
\hline Body Mass Index $\left(\mathrm{kg} / \mathrm{m}^{2}\right)$ & $28.46^{+} \pm 3.50$ & $34,88^{*+} \pm 5.71$ & $30.06^{+} \pm 4.87$ \\
\hline Body Fat (kg) & $24.82^{+} \pm 5.67$ & $34.74^{\star \#} \pm 8.45$ & $27.29^{+} \pm 8.07$ \\
\hline Body Fat Percentage (\%) & $34.81^{+} \pm 2.36$ & $40.66^{\star \#} \pm 2.74$ & $36.41^{+} \pm 3.50$ \\
\hline Soft Lean Mass (kg) & $41.91 \pm 5.17$ & $45.19 \pm 6.20$ & $42.38 \pm 5.20$ \\
\hline Left Arm Fat (kg) & $1.54^{\#} \pm 0.43$ & $2.27^{\star \#} \pm 0.57$ & $1.76^{*} \pm 0.57$ \\
\hline Right Arm Fat (kg) & $1.64^{+} \pm 0.47$ & $2.27^{\star \#} \pm 0.56$ & $1.74^{+} \pm 0.61$ \\
\hline Trunk Fat (kg) & $12.75^{+} \pm 2.90$ & $17.87^{\star \#} \pm 4.35$ & $14.03^{+} \pm 4.12$ \\
\hline Left Leg Fat (kg) & $4.35^{+} \pm 0.95$ & $6.15^{\star *} \pm 1.50$ & $4.84^{+} \pm 1.37$ \\
\hline Right Leg Fat(kg) & $4.52^{+} \pm 1.06$ & $6.18^{\star \#} \pm 1.47$ & $4.87^{+} \pm 1.40$ \\
\hline Cellulite Grade & $1.91^{\mathrm{a} \#} \pm 0.83$ & $2.88^{\mathrm{a}} \pm 0.34$ & $2.05^{\mathrm{a} \star} \pm 0.83$ \\
\hline
\end{tabular}

$\mathrm{a}=$ Kruskal Wallis followed by Post Hoc Mann-Whiney

${ }^{*} \mathrm{p}<0.05$ compared to control, \# $\mathrm{p}<0,05$ compared to the 42 -day treatment group One Way ANOVA followed by Post Hoc Bonferroni.

* significant $(\mathrm{p}<0.05)$ compared to control group

+ significant $\mathrm{p}<0.05$ compared to the 28 -day treatment group \# significant $\mathrm{p}<0.05$ compared to the 42 -day treatment group 
Table 3: Proportion Analysis of Lifestyle and Compliance in the 28-day Treatment Group and the 42-day Treatment Group.

\begin{tabular}{|c|c|c|}
\hline \multirow[t]{2}{*}{ Lifestyle / Compliance } & $\begin{array}{l}\text { 28-Day Treatment } \\
\text { Group }\end{array}$ & $\begin{array}{l}\text { 42-Day Treatment } \\
\text { Group }\end{array}$ \\
\hline \multirow{2}{*}{\multicolumn{3}{|c|}{ Estimated caloric intake }} \\
\hline & & \\
\hline Corresponding & $14(87.5 \%)$ & $14(70 \%)$ \\
\hline Not appropriate / excessive & $2(12.5 \%)$ & $6(30 \%)$ \\
\hline \multicolumn{3}{|c|}{ Estimated Lipid intake } \\
\hline Corresponding & $16(100 \%)$ & $20(100 \%)$ \\
\hline Not appropriate / excessive & $0(0 \%)$ & $0(0 \%)$ \\
\hline \multicolumn{3}{|c|}{ Physical/sports activities } \\
\hline a. Bad & $16(100 \%)$ & $15(75 \%)$ \\
\hline b. Less & $0(0 \%)$ & $4(20 \%)$ \\
\hline c. Enough & $0(0 \%)$ & $1(5 \%)$ \\
\hline d. Very good & $0(0 \%)$ & $0(0 \%)$ \\
\hline e. High & $0(0 \%)$ & $0(0 \%)$ \\
\hline \multicolumn{3}{|c|}{ Compliance taking test drugs } \\
\hline a. High & $15(93.8 \%)$ & $18(90 \%)$ \\
\hline b. Medium & $0(0 \%)$ & $0(0 \%)$ \\
\hline c. Low & $1(6.3 \%)$ & $2(10 \%)$ \\
\hline
\end{tabular}

${ }^{\mathrm{a}}$ Chi-Square Test; ${ }^{\mathrm{b}}$ Mann-Whitney

p-value $<0.05$

exercise during the study was also recorded in the notebook and the results were assessed. Calculation of caloric value was carried out using the Harris-Benedict formula. ${ }^{11}$ Drug compliance was assessed using the Morisky Medication Adherence Scale (MMAS-8) questionnaire. Lifestyle and drug compliance analysis are listed in Table 3.

The results showed that most participants were adherent in taking test drugs. The percentage of adherence in the 28-day treatment group was $93 \%$ as one subject in the 28 -day forgot to take the drug while traveling and therefore did not take the test drug for several days. Two subjects in the 42-day treatment group experienced pain and menstrual disturbance during the study and decided to delay in taking the test drug, hence it explains $90 \%$ adherence in the 42 -day treatment group. Lifestyle and compliance in this study did not show any significant difference, suggesting that lifestyle and adherence did not affect the outcome of the study.

\section{Effects without the administration of test drugs in the control group}

The results of comparison between pre and post in control groups showed no significant difference for all parameters except in fasting blood glucose (FGB). However, there were clinical improvements in some parameters, such as lipid profile, including total cholesterol, and LDL, and body fat composition, including body weight, BMI, body fat, body fat percentage (BFP), soft lean mass (SLM), left arm fat, trunk fat, and left thigh fat. The result of pre and post control group can be seen in Table 4 .

\section{Effects of test drug on the 28-day treatment group}

Only cellulite grade showed a significant improvement in the 28-day treatment group. Although not statistically significant, there were clinical improvements in triglyceride parameters, total cholesterol, HDL, LDL, cholesterol/HDL ratio, LDL/ HDL ratio, and BFP. The statistical analysis of the 28-day treatment group can be seen in Table 5 .
Table 4: Effects without Test Drug on Control Group.

\begin{tabular}{|c|c|c|c|}
\hline Parameter Effectiveness & $\begin{array}{c}\text { Pre } \\
n=11 \\
\text { Mean } \pm \text { SD }\end{array}$ & $\begin{array}{c}\text { Post } \\
n=11 \\
\text { Mean } \pm \text { SD }\end{array}$ & $\begin{array}{c}\text { Mean } \\
\text { Difference }\end{array}$ \\
\hline Triglyceride (mg/dL) & $99.09 \pm 74.08$ & $88.18 \pm 56.77$ & 10.91 \\
\hline Total cholesterol (mg/dL) & $169.64 \pm 20.98$ & $172.27 \pm 18.59$ & -2.64 \\
\hline $\mathrm{HDL}(\mathrm{mg} / \mathrm{dL})$ & $46.35 \pm 8.34$ & $49.06 \pm 7.18$ & 2.72 \\
\hline $\mathrm{LDL}(\mathrm{mg} / \mathrm{dL})$ & $107.55 \pm 19.16$ & $112.82 \pm 17.25$ & -5.27 \\
\hline Cholesterol/HDL Ratio & $3.77 \pm 0.87$ & $3.58 \pm 0.67$ & 0.19 \\
\hline LDL/HDL Ratio & $2.38 \pm 0.56$ & $2.34 \pm 0.47$ & 0.04 \\
\hline Fasting Blood Sugar (mg/dL) & $88.27 \pm 5.02$ & $93.09 \pm 5.56$ & $-4.82^{*}$ \\
\hline Weight (kg) & $70.73 \pm 11.19$ & $71.4 \pm 11.64$ & -0.67 \\
\hline Body Mass Index $\left(\mathrm{kg} / \mathrm{m}^{2}\right)$ & $28.46 \pm 3.50$ & $28.58 \pm 3.62$ & -0.12 \\
\hline Body Fat (kg) & $24.82 \pm 5.67$ & $25.18 \pm 5.84$ & -0.36 \\
\hline Body Fat Percentage (\%) & $34.81 \pm 2.36$ & $34.95 \pm 2.31$ & -0.15 \\
\hline Soft Lean Mass (kg) & $41.91 \pm 5.17$ & $42.17 \pm 5.25$ & -0.26 \\
\hline Left Arm Fat (kg) & $1.54 \pm 0.43$ & $1.62 \pm 0.44$ & -0.08 \\
\hline Right Arm Fat (kg) & $1.64 \pm 0.47$ & $1,6 \pm 0.44$ & 0.04 \\
\hline Trunk Fat (kg) & $12.75 \pm 2.90$ & $12.96 \pm 2.99$ & -0.22 \\
\hline Left Leg Fat (kg) & $4.35 \pm 0.95$ & $4.43 \pm 1.06$ & -0.08 \\
\hline Right Leg Fat(kg) & $4.52 \pm 1.06$ & $4.5 \pm 1.00$ & 0.02 \\
\hline Cellulite Grade & $1.91 \pm 0.83$ & $1.73 \pm 0.79$ & 0.18 \\
\hline
\end{tabular}

Paired t-test

* $=$ Significant $(\mathrm{p}<0.05)$

Table 5: Effects of Test Drug on the 28-day Treatment Group.

\begin{tabular}{|c|c|c|c|}
\hline Parameter Effectiveness & $\begin{array}{c}\text { Pre } \\
n=16 \\
\text { Mean } \pm \text { SD }\end{array}$ & $\begin{array}{c}\text { Post } \\
n=16 \\
\text { Mean } \pm \text { SD }\end{array}$ & $\begin{array}{c}\text { Mean } \\
\text { Difference }\end{array}$ \\
\hline Triglyceride (mg/dL) & $134.88 \pm 71.92$ & $130.63 \pm 74.41$ & $4.25^{\mathrm{a}}$ \\
\hline Total cholesterol (mg/dL) & $189.06 \pm 36.07$ & $182.06 \pm 29.83$ & $7^{a}$ \\
\hline $\mathrm{HDL}(\mathrm{mg} / \mathrm{dL})$ & $45.18 \pm 9.33$ & $45.63 \pm 9.76$ & $0.45^{\mathrm{a}}$ \\
\hline $\mathrm{LDL}(\mathrm{mg} / \mathrm{dL})$ & $120.63 \pm 29.85$ & $117.94 \pm 29.85$ & $2.69^{\mathrm{a}}$ \\
\hline Cholesterol/HDL Ratio & $4.311 \pm 1.10$ & $4.09 \pm 0.82$ & $0.22^{\mathrm{a}}$ \\
\hline LDL/HDL Ratio & $2.77 \pm 0.85$ & $2.67 \pm 0.71$ & $0.1^{\mathrm{a}}$ \\
\hline Fasting Blood Sugar (mg/dL) & $91.19 \pm 7.64$ & $92.81 \pm 6.81$ & $-1.63^{a}$ \\
\hline Weight (kg) & $84.68 \pm 15.23$ & $85.26 \pm 14.92$ & $-0.58^{a}$ \\
\hline Body Mass Index $\left(\mathrm{kg} / \mathrm{m}^{2}\right)$ & $34.88 \pm 5.71$ & $35.13 \pm 5.58$ & $-0.25^{a}$ \\
\hline Body Fat (kg) & $34.74 \pm 8.45$ & $34.84 \pm 8.58$ & $-0.1^{a}$ \\
\hline Body Fat Percentage (\%) & $40.66 \pm 2.74$ & $40.49 \pm 3.32$ & $0.17^{\mathrm{a}}$ \\
\hline Soft Lean Mass (kg) & $45.19 \pm 6.20$ & $45.66 \pm 6.21$ & $-0.47^{a}$ \\
\hline Left Arm Fat (kg) & $2.27 \pm 0.57$ & $2.24 \pm 0.57$ & $0.03^{a}$ \\
\hline Right Arm Fat (kg) & $2.27 \pm 0.56$ & $2.19 \pm 0.56$ & $0.08^{a}$ \\
\hline Trunk Fat (kg) & $17.87 \pm 4.35$ & $17.94 \pm 4.41$ & $-0.07^{a}$ \\
\hline Left Leg Fat (kg) & $6.15 \pm 1.50$ & $6.24 \pm 1.55$ & $-0.09^{a}$ \\
\hline Right Leg Fat(kg) & $6.18 \pm 1.47$ & $6.22 \pm 1.54$ & $-0.04^{a}$ \\
\hline Cellulite Grade & $2.88 \pm 0.34$ & $2.56 \pm 0.51$ & $0.31^{\mathrm{b} *}$ \\
\hline
\end{tabular}

${ }^{\mathrm{a}}$ paired $t$-test ${ }^{\mathrm{b}}$ Wilcoxon test

* = Significant $(\mathrm{p}<0.05)$ 
Table 6: Effects of Test Drug on the 42-day Treatment Group.

\begin{tabular}{|c|c|c|c|}
\hline Parameter Effectiveness & $\begin{array}{c}\text { Pre } \\
n=20 \\
\text { Mean } \pm \text { SD }\end{array}$ & $\begin{array}{c}\text { Post } \\
n=20 \\
\text { Mean } \pm \text { SD }\end{array}$ & $\begin{array}{c}\text { Mean } \\
\text { Difference }\end{array}$ \\
\hline Triglyceride (mg/dL) & $89.10 \pm 45.94$ & $93.05 \pm 47.99$ & -3.95 \\
\hline Total Cholesterol (mg/dL) & $178.65 \pm 23.83$ & $174.20 \pm 19.44$ & 4.45 \\
\hline $\mathrm{HDL}(\mathrm{mg} / \mathrm{dL})$ & $49.35 \pm 11.67$ & $46.80 \pm 9.30$ & $-2.55^{*}$ \\
\hline $\mathrm{LDL}(\mathrm{mg} / \mathrm{dL})$ & $117.80 \pm 16.78$ & $113.90 \pm 14.71$ & 3.9 \\
\hline Cholesterol/HDL Ratio & $3.73 \pm 0.68$ & $3.82 \pm 0.70$ & -0.09 \\
\hline LDL/HDL Ratio & $2.48 \pm 0.54$ & $2.51 \pm 0.53$ & -0.03 \\
\hline Fasting Blood Sugar (mg/dL) & $88.65 \pm 7.21$ & $86.95 \pm 8.24$ & 1.7 \\
\hline Weight $(\mathrm{kg})$ & $73,83 \pm 13,66$ & $74,01 \pm 13,89$ & -0.18 \\
\hline Body Mass Index $\left(\mathrm{kg} / \mathrm{m}^{2}\right)$ & $30.06 \pm 4.87$ & $30.13 \pm 4.97$ & -0.07 \\
\hline Body Fat (kg) & $27.29 \pm 8.07$ & $27.62 \pm 8.18$ & -0.34 \\
\hline Body Fat Percentage (\%) & $36.41 \pm 3.50$ & $36.75 \pm 3.65$ & -0.34 \\
\hline Soft Lean Mass (kg) & $42.38 \pm 5.20$ & $42.22 \pm 5.35$ & 0.16 \\
\hline Left Arm Fat (kg) & $1.76 \pm 0.57$ & $1.85 \pm 0.77$ & -0.09 \\
\hline Right Arm Fat (kg) & $1.74 \pm 0.61$ & $1.63 \pm 0.52$ & 0.12 \\
\hline Trunk Fat (kg) & $14.03 \pm 4.12$ & $14.25 \pm 4.27$ & -0.21 \\
\hline Left Leg Fat (kg) & $4.84 \pm 1.37$ & $5.02 \pm 1.58$ & $-0.18^{*}$ \\
\hline Right Leg Fat(kg) & $4.87 \pm 1.40$ & $4.97 \pm 1.55$ & -0.11 \\
\hline Cellulite Grade & $2.05 \pm 0.83$ & $2.10 \pm 0.91$ & -0.05 \\
\hline
\end{tabular}

paired_t_test

* $=$ Significant $(\mathrm{P}<0.05)$

\section{Effects of test drug on the 42-day treatment group}

The result of the 42-day treatment showed significant differences on HDL and left thigh fat. The HDL parameter showed a significant decrease, whereas left thigh fat showed a significant increase. Similar to previous groups, although other parameters did not show any statistically significant difference, some parameters showed clinical improvements. These parameters were including total cholesterol, LDL, FBG, and right arm fat. Effect of test drug on the 42-day treatment group can be seen in Table 6 .

Comparison of mean values of pre and post parameters between control group, the 28-day, and the 42-day treatment groups

The comparison between each group can be seen in Table 7. The results showed there was no statistically significant difference in parameters left arm fat, right arm fat, and cellulite. Statistically significant differences showed in HDL and cholesterol/HD ratios (Between what and what). HDL value in control group was better than the HDL value of the 42-day treatment group, whereas cholesterol/HDL ratio of the 28-day treatment group was better than in the 42-day treatment group and control group.

\section{DISCUSSION}

The results showed that not every parameter gave significant changes. There were significant differences on HDL and cholesterol/HDL ratio. The difference in HDL parameters was found in the control group with the 42-day treatment group, while the difference in cholesterol/HDL ratio was found in the 28 -day with the 42 -day treatment groups. HDL value in control group was better than in the 42-day treatment group. The cholesterol/HDL ratio of the 28-day treatment group was better than the 42-day treatment group. In the absence of other explanations,
Table 7: The Mean Difference between Pre and Post Parameters in Control Group, the 28-day Treatment Group, and the 42-day Treatment Group.

\begin{tabular}{|c|c|c|c|}
\hline Parameter & $\begin{array}{c}\text { Control } \\
n=11 \\
\text { Mean } \pm \text { SD }\end{array}$ & $\begin{array}{c}\text { 28-day Treat- } \\
\text { ment } \\
n=16 \\
\text { Mean } \pm \text { SD }\end{array}$ & $\begin{array}{c}\text { 42-day Treat- } \\
\text { ment } \\
n=20 \\
\text { Mean } \pm \text { SD }\end{array}$ \\
\hline Triglyceride (mg/dL) & $10.90 \pm 32.81$ & $4.25 \pm 31.27$ & $-3.95 \pm 37.52$ \\
\hline Total Cholesterol (mg/dL) & $-2.63 \pm 11.36$ & $7.00 \pm 18.76$ & $4.45 \pm 18.05$ \\
\hline $\mathrm{HDL}(\mathrm{mg} / \mathrm{dL})$ & $2.72^{*} \pm 4.74$ & $0.45 \pm 3.23$ & $-2.55^{\star} \pm 4.97$ \\
\hline $\mathrm{LDL}(\mathrm{mg} / \mathrm{dL})$ & $-5.27 \pm 11.06$ & $2.69 \pm 15.53$ & $3.90 \pm 14.19$ \\
\hline Cholesterol/HDL Ratio & $0.19 \pm 0.27$ & $0.22^{\#} \pm 0.48$ & $-0.09^{+} \pm 0.26$ \\
\hline LDL/HDL Ratio & $0.04 \pm 0.21$ & $0.10 \pm 0.39$ & $-0.03 \pm 0.21$ \\
\hline Fasting Blood Sugar (mg/dL) & $-4.82 \pm 5.08$ & $-1.63 \pm 7.83$ & $1.70 \pm 9.41$ \\
\hline Weight $(\mathrm{kg})$ & $-0.67 \pm 1.30$ & $-0.58 \pm 1.19$ & $-0.18 \pm 1.37$ \\
\hline Body Mass Index $\left(\mathrm{kg} / \mathrm{m}^{2}\right)$ & $-0.12 \pm 0.61$ & $-0.25 \pm 0.50$ & $-0.07 \pm 0.55$ \\
\hline Body Fat (kg) & $-0.36 \pm 1.14$ & $-0.09 \pm 1.21$ & $-0.34 \pm 0.99$ \\
\hline Body Fat Percentage (\%) & $-0.15 \pm 1.50$ & $0.16 \pm 1.26$ & $-0.34 \pm 1.21$ \\
\hline Soft Lean Mass (kg) & $-0.26 \pm 1.44$ & $-0.46 \pm 1.41$ & $0.16 \pm 1.17$ \\
\hline Left Arm Fat (kg) & $-0.08 \pm 0.25$ & $0.05 \pm 0.15$ & $-0.09 \pm 0.57$ \\
\hline Right Arm Fat (kg) & $0.04 \pm 0.04$ & $0.09 \pm 0.31$ & $0.12 \pm 0.39$ \\
\hline Trunk Fat (kg) & $-0.22 \pm 0.66$ & $0.05 \pm 0.57$ & $-0.21 \pm 0.48$ \\
\hline Left Leg Fat (kg) & $-0.07 \pm 0.41$ & $-0.03 \pm 0.22$ & $-0.18 \pm 0.34$ \\
\hline Right Leg Fat(kg) & $0.02 \pm 0.18$ & $0.003 \pm 0.21$ & $-0.11 \pm 0.26$ \\
\hline Cellulite Grade & $0.18 \pm 0.75$ & $0,31 \pm 0.48$ & $-0.05 \pm 0.69$ \\
\hline
\end{tabular}

The data were analyzed using repeated ANOVA followed by Post Hoc Tamhane's. ${ }^{*} \mathrm{p}<0.05$ compared to control group

${ }^{+} \mathrm{p}<0.05$ compared to the 28 -day treatment group

" $\mathrm{p}<0.05$ compared to the 42 -day treatment group
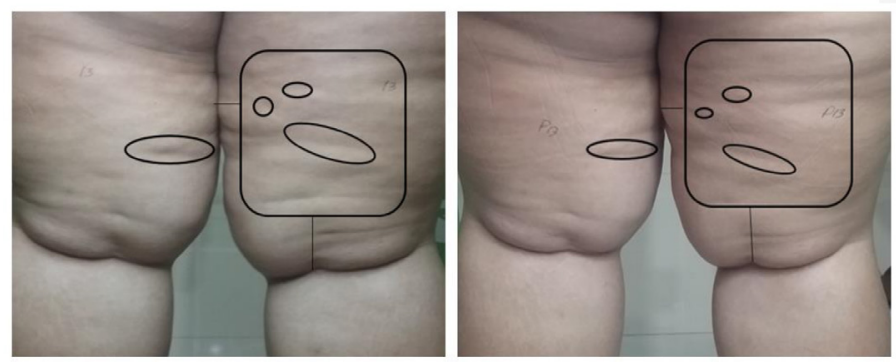

Figure 1: Cellulite Changes on Subject in Treatment Group: Before (Left) and After (Right) Treatment.

the control group showed a better result in some parameters compared to groups with intervention is not a novel thing. Similar condition was shown in the study of Attari et al. ${ }^{12}$ Research of Attari et al. ${ }^{12}$ using 1 gram of ginger supplement 2 times daily for 12 weeks in 80 obese women aged 18-45 years with BMT $30-40 \mathrm{~kg} / \mathrm{m} 2$ showed significant results in triglyceride decrease, cholesterol/HDL ratio, LDL/HDL ratio, body weight, BMI, waist and hip circumference.

Although other parameters did not show any statistically significant difference, there were clinical improvements. The 28-day treatment group showed improvements in triglyceride, total cholesterol, HDL, LDL, LDL/HDL ratio, BFP, right and left arm fat, and FGB. The 42-day group showed improvements in total cholesterol, LDL, FGB, and right arm fat. Groups who received the test drug showed better improvements 
in some parameters compared to the control group, including total cholesterol, LDL, LDL/HDL ratio, FBG, body weight, BMI, body fat, BFP, SLM, left and right arm fat, trunk fat, left thigh fat, and cellulite grade.

Furthermore, higher doses showed better results in increasing concentration and thickness of collagen and decreasing the adipocyte cell diameter. ${ }^{3}$ From the experimental study, ginger may significantly lower blood glucose in animals, ${ }^{13-16}$ whereas, in humans, the results are inconsistent. ${ }^{12}$ Ginger extract can reduce the levels of lipid, ${ }^{17}$ total cholesterol, and LDL in rats. ${ }^{18}$ Nammi et al. ${ }^{19}$ reported that ethanol extract in ginger can reduce total cholesterol, LDL, triglycerides in mice with high-fat diets. Research from Atashak et al..$^{20}$ and Bordia et al. ${ }^{21}$ showed that consumption of 4 grams of ginger powder daily for 3 months in non-diabetic patients have no significant effect on lipid profile and blood sugar, while research from Andallu et al. ${ }^{22}$ showed that consuming $3 \mathrm{mg}$ of powdered dried ginger daily for 30 days significantly decreased total cholesterol, LDL, and VLDL in diabetic patients.

Different results of ginger in decreasing lipid profile according to Ali et al. ${ }^{23}$ is related to its mechanism of action. Ginger reduced lipid profile by decreasing fat absorption, cholesterol cell biosynthesis, and increasing conversion of cholesterol into bile acids. Therefore, subjects with higher cholesterol level will show a greater decrease. In this study, the group with the highest baseline in cholesterol level also showed the greatest decrease. The differences in the given form of ginger, preparation method, and length of study may also be the contributing factors. ${ }^{12}$

C. asiatica reduces cellulite by increasing collagen synthesis which can restore skin elasticity and firmness. Usually, C. asiatica is used in a cream dosage form. In the study of Primastuti et al. ${ }^{24}$ the combination of C. asiatica leaf and green coffee bean in cream dosage form given for 84 days showed a significant result in reducing cellulite and abdominal circumference. Research on the effectiveness of anticellulite from C. asiatica extract in oral preparations is very limited. Besides containing asiaticoside, C. asiatica also contains flavonoid compounds, which known to inhibit lipid peroxidation and increases oxygen supply and skin nutrients. The oxygen supply is important factor for hydroxylation of prolineandlysine in forms pro-collagen that increase collagen synthesis. ${ }^{25-26}$

In this study, the extract was only given orally and different parameters were used to measure cellulite. The effectivity of $C$. asiatica in collagen can be seen by measuring the cellulite grade. A significant difference in grade of cellulite was found in the pre and post analysis of the 28-day treatment group, whereas no significant change observed in the control group and the 42-day treatment group. It interesting that administration of herbal test in 28 days showed a tendency of better improvement on many parameters than that on 42 days. It is probably because the 28-day treatment group had a higher baseline values than the 42 -day treatment group. It seems that the effect was more significantly displayed in more severe cellulite grade and worse lipid profile. However, the improvement is not statistically significant. This little effect is likely because the active ingredient content in the dose given is too small. It needs further study with a higher active ingredient content to confirm the effectiveness.

\section{CONCLUSION}

The nanoencapsulated extract of Centella asiatica leaf and red ginger (Zingiber officinale) showed that the administration for 28 days could significantly improve the cellulite grade. There was a significant improvement in the mean difference of the cholesterol/HDL ratio, which showed that the 28-day treatment group was better than the 42-day treatment group. Although the parameters of body fat composition and lipid profiles did not show statistically significant improvements, there were clinical improvements observed in both parameters compared to control group. The 28-day group showed improvements in triglyceride, total cholesterol, HDL, LDL, LDL/HDL ratio, BFP, right arm fat, left arm fat, and FBG. The 42-day treatment group showed improvements in total cholesterol, LDL, FBG, and right arm fat. Improved parameters compared to the control group were included total cholesterol, LDL, LDL/HDL ratio, FBG, body weight, BMI, body fat, BFP, left arm fat, right arm fat, trunk fat, left thigh fat, and cellulite grade.

\section{ACKNOWLEDGEMENT}

The researchers would like to thank the LIPI Biotechnology Research Center who has funded this research, and to the Faculty of Pharmacy, Universitas Gadjah Mada who has facilitated this research.

\section{CONFLICT OF INTEREST}

The authors declare no conflict of interest.

\section{ABBREVIATIONS USED}

BMI: Body Mass Index; LDL: Low Density Lipoprotein; FGB: Fasting Blood Glucose; BFP: Body Fat Percentage; SLM: Soft Lean Mass.

\section{SUMMARY}

Our study is the first clinical trial to report that the nanoencapsulated extract combination of $C$. asiatica and $Z$. officinale can improve cellulite, lipid profile, and subcutaneous fat.

\section{REFERENCES}

1. Bonté F, Dumas M, Chaudagne C, Meybeck A. Comparative activity of asiaticoside and madecassoside on type I and III collagen synthesis by cultured human fibroblasts. Ann Pharm Fr. 1995;53(1):38-42

2. Lucassen GW, Van der Sluys WL, Van Herk JJ, Nuijs AM, Wierenga PE, Barel $A O$, et al. The effectiveness of massage treatment on cellulite as monitored by ultrasound imaging. Skin Res Technol. 1997;3(3):154-60.

3. Ikawati Z, Murwanti R, Meliana Y, Kartika W. The effect of nanoencapsulated Centella asiatica I and Zingiber officinale rosc. Rubrum combination to promote collagen synthesis and decrease the diameter of adipocyte cells in female wistar rats. Int J Pharm Sci Res. 2016;7(5):1909-14.

4. Goyal A, Kumar S, Nagpal M, Singh I, Arora S. Potential of novel drug delivery systems for herbal drugs. Ind J Pharm Edu Res. 2011;45(3):225-35.

5. Bylka W, Znajdek-Awizen P, Studzinska-Sroka E, Brzezinska M. Centella asiatica in cosmetology. Postepy Dermatol Alergol. 2013;30(1):46-9.

6. Bylka W, Znajdek-Awizen P, Studzinska-Sroka E, Danczak-Pazdrowska A, Brzezinska M. Centella asiatica in dermatology: An overview. Phytother Res. 2014;28(8):1117-24.

7. Butt MS, Sultan MT. Ginger and its health claims: molecular aspects. Crit Rev Food Sci Nutr. 2011;51(5):383-93.

8. Mashhadi NS, Ghiasvand R, Askari G, Hariri M, Darvishi L, Mofid MR. Antioxidative and anti-inflammatory effects of ginger in health and physical activity: review of current evidence. Int J Prev Med. 2013;4(1):S36-42.

9. Yulianita B, Kardono BS, Simanjuntak P. Stimulantia effectiveness of extract green tea, red ginger and centella lozenges. J Young Pharm. 2017;9(1):S70-2

10. Ahmed R, Seth V, Pasha S, Banerjee B. Influence of dietary ginger (Zingiber officinales Rosc) on oxidative stress induced by malathion in rats. Food Chem Toxicol. 2000;38(5):443-50.

11. Compher C, Cato R, Bader J, Kinosian B. Harris-Benedict equations do not adequately predict energy requirements in elderly hospitalized African Americans. J Natl Med Assoc. 2004;96(2):209-14.

12. Attari V, Mahluji S, Jafarabadi AM, Ostadrahimi A. Effects of Supplementation with Ginger (Zingiber officinale Roscoe) on Serum Glucose, Lipid Profile and Oxidative Stress in Obese Women: A Randomized, Placebo-Controlled Clinical Trial. Pharm Sci. 2015;21(4):184-91.

13. Bhandari U, Kanojia R, Pillai KK. Effect of ethanolic extract of Zingiber officinale on dyslipidaemia in diabetic rats. J Ethnopharmacol. 2005;97(2):227-30.

14. Li Y, Tran VH, Kota BP, Nammi S, Duke CC, Roufogalis BD. Preventative effect of Zingiber officinale on insulin resistance in a high-fat high-carbohydrate diet-fed rat model and its mechanism of action. Basic Clin Pharmacol Toxicol. 2014;115(2):209-15

15. Saravanan G, Ponmurugan P, Deepa MA, Senthilkumar B. Anti-obesity action of gingerol: Effect on lipid profile, insulin, leptin, amylase and lipase in male obese rats induced by a high-fat diet. J Sci Food Agric. 2014;94(14):2972-7.

16. Al-Amin ZM, Thomson M, Al-Qattan KK, Peltonen-Shalaby R, Ali M. Anti-diabetic and hypolipidaemic properties of ginger (Zingiber officinale) in streptozotocin- 
induced diabetic rats. Br J Nutr. 2006;96(4):660-6.

17. Nazish I, Ansari SH, Arora P, Ahmad A. Antiobesity activity of Zingiber officinale. Phcog J. 2016;8(5):440-6.

18. Al-Noory AS, Amreen A, Hymoor S. Antihyperlipidemic effects of ginger extracts in alloxan-induced diabetes and propylthiouracil-induced hypothyroidism in (rats). Phcog Res. 2013;5(3):157-61.

19. Nammi S, Sreemantula S, Roufogalis BD. Protective effects of ethanolic extract of Zingiber officinale rhizome on the development of metabolic syndrome in high-fat diet-fed rats. Basic Clin Pharmacol Toxicol. 2009;104(5):366-73.

20. Atashak S, Peeri M, Azarbayjani MA, Stannard SR. Effects of ginger (Zingiber officinale Roscoe) supplementation and resistance training on some blood oxidative stress markers in obese men. J Exerc Sci Fit. 2014;12(1):26-30.

21. Bordia A, Verma SK, Srivastava KC. Effect of ginger (Zingiber officinale Rosc.) and fenugreek (Trigonella foenumgraecum L.) On blood lipids, blood sugar and platelet aggregation in patients with coronary artery disease. Prostaglandins Leukot Essent Fatty Acids. 1997;56(5):379-84.

22. Andallu B, Radhika B, Suryakantham V. Effect of aswagandha, ginger and mulberry on hyperglycemia and hyperlipidemia. Plant Foods Hum Nutr
2003;58(3):1-7.

23. Ali BH, Blunden G, Tanira MO, Nemmar A. Some phytochemical, pharmacological and toxicological properties of ginger (Zingiber officinale Roscoe): a review of recent research. Food Chem Toxicol. 2008;46(2):409-20.

24. Primastuti RF, Wih WL, Mun'im A. Effect of a combination of extract of Centella asiatica L. Leaves and extract of green coffee (Coffea canephora robusta P.) Beans in a cream preparation for grade 1-3 cellulite and slimming. Makara $\mathrm{J}$ Sci. 2013;17:1-5

25. Novriansyah R. Collagen Density Difference around Wistar Wisdom Injuries in Conventional Cases and Oklusive Hydrocolloid Covers For 2 and 14 days. Thesis, Master of Biomedical Science and Specialist Doktor Surgey, Diponegoro University, Semarang, Indonesia. 2008.

26. Zainol MM, Abdul-Hamid A, Abu Bakar F, Pak Dek S. Effect of Different Drying Methods on the Degradation of Selected Flavonoids in Centella asiatica, International Food Research Journal. 2009;16:531-7.

Article History: Submission Date : 23-11-2017; Revised Date : 12-04-2018; Acceptance Date : 08-06-2018.

Cite this article: Kristiyani A, Meliana Y, Purwoko RY, Ikawati Z. Clinical Trial of Nanoencapsulated Centella asiatica and Zingiber officinale to Improve Cellulite and Subcutaneous Adipolysis. J Young Pharm. 2018;10(3):344-9. 